\title{
Phrometeu/Prometeu: o transe, o poder e a gênese no Titã de Glauber Rocha e Murilo Mendes
}

\author{
Larissa Costa da Mata ${ }^{1}$ \\ Universidade Federal de Santa Catarina, Florianópolis, Brasil
}

Resumo: O mito de Prometeu na literatura de Hesíodo (em Teogonia e em 0 trabalho e os dias) e de Ésquilo (em Prometeu acorrentado) encena manifestações diversas da origem da cultura, ora como a instauração do progresso pelo roubo do fogo, ora como a aproximação entre o titã e os homens graças ao ato criminoso e à punição tirânica de Zeus. Focaremos duas versões do mito na literatura brasileira, a de Glauber Rocha em Riverão Sussuarana (1978) e a de Murilo Mendes no poema "Novíssimo Prometeu", de O visionário (1941), a partir da noção nietzschiana da genealogia - compreendida como o conflito entre potências opostas e a irrupção de um começo imprevisível na história. Ao lado dos surrealistas dissidentes do Colégio de Sociologia, Mendes e Rocha conceberam Prometeu, respectivamente, como uma origem bipolar, descentralizadora do cânone da literatura, e como um revolucionário em conflito com o poder dos Estados ditatoriais.

Palavras-chave: Prometeu; Origem; Murilo Mendes; Glauber Rocha.

Title: Phrometeu / Prometheus: trance, power and genesis according to the titan by Glauber Rocha and Murilo Mendes

Abstract: The myth of Prometheus by Hesiod (in Theogony and Works and Days) and Aeschylus (in Prometheus Bound) perform different manifestations of origin of culture: sometimes as the establishment of progress due to fire robbery, sometimes as the relationship between the titan and humanity as a result of his criminal act and tyrannical punishment of Zeus. This essay will analyze two different versions of such myth in Brazilian literature: Glauber Rocha's in Riveirão Sussuarana (1978) and Murilo Mendes's in the poem "Novíssimo Prometeu", which appeared on the book O Visionário (1941), according to Nietzschean conception of genealogy - the conflict of opposite forces and the burst of a beginning unpredictable by History. Together with surrealist dissident intellectuals from the Collège de Sociologie, Mendes and Rocha conceived Prometheus as a bipolar foundation, decentralizing literary canon, and as a revolutionary fighting against the power of dictatorial states respectively.

Keywords: Prometheus; Origin; Murilo Mendes; Glauber Rocha.

\footnotetext{
${ }^{1}$ Doutora em Teoria da Literatura pela Universidade Federal de Santa Catarina (UFSC), fez pósdoutorado junto ao Programa de Pós-Graduação em Literatura da Universidade de São Paulo (USP) com bolsa de pós-doutorado júnior do CNPq. Orcid: https://orcid.org/ 0000-0001-5614-0182 E-mail: larissa.mata@gmail.com
} 


\section{Introdução}

O mito de Prometeu, como vemos nas versões de Hesíodo (em Teogonia, do verso 507 ao 616, e em $O$ trabalho e os dias, do verso 42 ao 105) e de Ésquilo (em Prometeu acorrentado), encena figurações diversas do fenômeno da origem da cultura. Essa se apresenta ora como a instauração do progresso pelo roubo do fogo (em Hesíodo), ora como a queda do titã à esfera dos homens graças em decorrência do ato criminoso do roubo do fogo e da tirania de Zeus, que sacrificara o corpo do herói (em Ésquilo) devorado indefinidamente por um abutre. Por sua vez, a interpretação filosófica do mito por Friedrich Nietzsche em $O$ nascimento da tragédia ou helenismo e pessimismo (1872) se dá como genealogia, a qual prima pela origem como um conflito entre potências opostas e como um começo que não obedece à cronologia histórica. Este texto pretende analisar duas versões do mito prometeico que guardam afinidades com a interpretação nietzschiana do mito na modernidade: a do fragmento "Phrometeu" de Riverão Sussuarana (1978), romance de Glauber Rocha (1939-1981), no qual o titã consiste no "nada" constitutivo de cada ser, e o poema "Novíssimo Prometeu" de Murilo Mendes (1901-1975), de O visionário (1941), em que Prometeu retorna na imagem dionisíaca, aberta e infinitamente renovada.

Vale ressaltar que Murilo Mendes e Glauber Rocha não foram os únicos a se dedicarem ao mito na cultura brasileira, visto se inserirem em uma série vasta que vai de Castro Alves a Flávio de Carvalho. Embora os intelectuais escolhidos para serem estudados neste texto se distanciem tanto quanto ao período em que produziram os textos em questão, como quanto aos gêneros escolhidos, um poema e o fragmento de um romance que se porta como a recusa de qualquer delimitação formal, podem ser aproximados por outros aspectos em comum além do mito do titã preso ao Cáucaso. Ambos foram "intelectuais nômades" que vivenciaram o exílio em cidades como Roma por motivos distintos: Murilo Mendes, entre 1950 e 1975, em busca da estabilidade econômica que não encontrara em terras brasileiras e Glauber Rocha, detrator da ditadura militar, esteve entre capitais europeias como a da França e a da Itália desde 1971, escrevendo Riverão Sussuarana após esse período. Aparte isso, os dois tiveram uma obra perpassada pela insurgência contra os totalitarismos e apresentaram uma compreensão da História como um campo de forças entre o antigo e o moderno, como fragmento e como circularidade, aspectos que se refletem na interpretação do mito de Prometeu fornecida por eles.

\section{Prometeu}

Segundo a Teogonia, quando Jápelo se casa com Clímena, filha do Oceano, tem quatro filhos como resultados da união: o "esforçado" Atlas, o "glorioso" Menécio, o "torpe" Epimeteu e Prometeu, "hábil e de versátil astúcia". Por uma razão que não está clara no excerto, Prometeu é preso a uma coluna para que tenha o fígado devorado por uma águia, até ser salvo por Héracles. Visto ter oferecido, ardilosamente, os restos de um boi destroçado 
a Zeus, o pai dos deuses se vinga do titã uma vez mais, escondendo o fogo dos homens (HESíODO, in: GUAL, 2009). Já em Trabalhos e os dias, Prometeu furta o fogo e leva-o aos mortais em um galho oco. Zeus reage criando uma mulher e pede para que Hermes the ofereça "um espírito cínico e um caráter volúvel"; essa mulher é Pandora, cuja caixa porta todos os males (HESÍODO, in: GUAL, 2009). Em Hesíodo, a insurgência de Prometeu (e a sua consequente punição) compreende o aspecto principal das narrativas, reforçando a conexão desse ato com uma perspectiva progressiva da história e com a fundação da cultura.

Por seu turno, Prometeu acorrentado, tragédia de Ésquilo, foca os padecimentos do titã e relembra os sofrimentos de outro herói, o irmão Atlas, como afirmam as ninfas do coro. O delito de Prometeu contra o poder supremo parte de sua crença nos benefícios que poderia trazer aos homens. Apesar da angústia e da opressão causadas pela pena divina, ele não se curva ao seu algoz, nem se arrepende dos atos cometidos. Por sua vez, lo, a ninfa filha de um rio, também vítima de Zeus, é destinada a vagar eternamente. Não por acaso, ambas as personagens guardam em comum a insurgência contra o autoritarismo do pai dos deuses:

\footnotetext{
Há uma oposição entre lo e Prometeu: ela é a vítima inocente dos desígnios pessoais e apaixonados de Zeus, à margem da justiça, ao passo que Prometeu é um delinquente rebelde e altivo diante dos desígnios desse tirano cuja justiça se rege por um arbitrário poder pessoal, segundo crê Prometeu. De algum modo, a paixão de Prometeu e a de lo coincidem em levantar uma acusação contra a crueldade do Soberano Zeus (GUAL, 2009, p. 85) .
}

Desse modo, a tragédia de Ésquilo perfaz uma reflexão sobre a violência (a silenciosa Bía), o poder (Krátos) e a tirania, pois Zeus é descrito com as expressões tyrannos e tyrannis: em nenhum momento é empregado o termo basileús, ou rei (GUAL, 2009).

Afora o caráter insurgente da personagem, vale salientar que ela enfatiza a existência da bipolaridade da origem na qual resiste, como força, uma instância negativa, não incluída no poder. Não fortuitamente, Raúl Antelo, a partir de Jean-Pierre Vernant, salienta a presença de duas vias inconciliáveis em Prometeu: a sua vertente iluminista e pirofórica - do fundador da cultura, herói que trouxe o fogo aos homens, permitindo-lhes o desenvolvimento da técnica - e a do plasticator ou do demiurgo criador, que poderá servir de metáfora ao artista e ao intelectual prometeicos. A união de ambos os polos reflete a ambiguidade das concepções modernas de sujeito, ao passo que, contemporaneamente, Prometeu se opõe ao poder e a sua própria soberania é mortífera, de modo que ele se torna rei e bode expiatório simultaneamente (ANTELO, 2010).

Como veremos, essa dupla forma de Prometeu, o instaurador da civilização e do progresso e, ao mesmo tempo, de um tempo circular por meio de seu corpo que se regenera a cada dia, nos sugere que a gênese esteja marcada pela cisão entre dois elementos opostos, o ser e a sua negatividade, e pela simultaneidade entre sofrimento punitivo e regeneração indócil. Tal leitura do mito percorre uma vertente da modernidade em que é visível a relação conflituosa com o poder do Estado, a que pertenceram os intelectuais reunidos em torno do Colégio de Sociologia como Georges Bataille e Roger Caillois, os quais, durante a emergência 
dos fascismos no velho continente, se dedicaram a investigar temas relacionados à ambiguidade do sagrado, ao poder e ao mito, bem como Glauber Rocha e Murilo Mendes, cujos textos estudados neste ensaio são contemporâneos ao regime ditatorial brasileiro e ao fascismo europeu e ao Estado Novo, respectivamente.

\section{0 transe e a gênese}

Friedrich Nietzsche propusera uma concepção de origem como a indecisão entre o sujeito e a estética, por meio da proliferação de bipolaridades, como aquela entre Apolo (a forma, a aparência) e Dioniso (a força, o tempo) em O nascimento da tragédia no espírito da música. O dionisíaco equivale a uma sorte de elemento transfigurador do apolíneo (por sua vez, predominante na rigidez e na organização do Estado dórico), inicialmente recusado como o bárbaro da cultura helênica. De acordo com a noção de genealogia nietzschiana, revisitada mais recentemente por filósofos como Roberto Esposito, a partir de Michel Foucault (FOUCAULT, 2007; ESPOSITO, 1999), o começo representa um conflito entre forças e impõe a diferença como valor preponderante. Em Riverão Sussuarana, texto híbrido, Glauber Rocha assume o atributo de personagem, provocando descentralizações do cânone e do autor, de modo que a origem, configurada como fundação negativa, desloca-se do conteúdo da História.

O livro de Glauber Rocha pertence a um conjunto de novelas que o cineasta pretendia disseminar pela editora Record, entre as quais constavam Unyverso, O fantastyko caso do tezouro vermelho, Teztamento da loukura, Orfeu e Bahya, mas que, diferentemente do volume de 1978, permaneceram inéditas (CÁMARA, 2012). Segundo o seu autor, Riverão oscilaria entre um texto memorialístico e um romance, mas não se decide entre nenhum das opções. Embora possa também ser lido a partir de seu caráter confessional, o qual perfura o texto paulatinamente (por meio do relato de um suposto encontro do cineasta com Guimarães Rosa, na ocasião em que apresentara a "Eztetyka da fome" na Itália , da narrativa sobre o falecimento da irmã Anecy Rocha etc.), o escopo de gêneros textuais tangenciados é mais amplo, posto que costure letras de canções, contos de autoria do próprio Glauber e de Anecy Rocha, narrativa policial, roteiro de cinema e parábola filosófica.

Ao aspecto híbrido e proliferante do gênero, é necessário acrescentarmos as escolhas da linguagem por Glauber, já encontradas em seus ensaios teóricos sobre o cinema. O autor se vale do desvio da gramática padrão e da inconstância como normas, no que diz respeito ao emprego da pontuação (muitas vezes suprimida), às substituições de " $s$ " por " $z$ ", de " $c$ " por " $k$ ", de "i" por " $\mathrm{y}$ ", de "j" por "g", ao uso inusitado de caixa alta, acoplamentos entre palavras (por justaposição ou por supressão de vírgulas). Contudo, não é possível discernir um "sistema" que uniformize tais desvios, ressaltando-se a inconstância como regra, dado que as "falhas", por vezes, não se repetem em outras recorrências da mesma palavra, ou de termos distintos com sílabas parecidas. Não fortuitamente, Mario Cámara designara a forma de Riverão Sussuarana como uma "coisa gritante", alinhando-o com outros livros que the 
foram contemporâneos: Água Viva (1973), de Clarice Lispector, Armadilha para Lamartine (1975), de Carlos e Carlos Sussekind e Galáxias (1984), de Haroldo de Campos.

A linguagem e a estrutura do texto não separam propriamente o romance do projeto cinematográfico glauberiano, na medida em que a narrativa é feita pela "montagem" entre os diferentes fragmentos nem sempre de forma linear, sem que se possa perceber a passagem de um a outro ou que haja uma separação entre os capítulos e segmentos. Tempo e espaço também seguem o fluxo do river / ribeirão, o qual não é contínuo, visto estar marcado por constantes interrupções, como observa Jair Tadeu da Fonseca (2012). Assim, o rio São Francisco, no livro de Glauber, se torna uma referência geográfica que atravessa o território brasileiro de Minas ao Nordeste como uma sorte de "fronteira móvel". Por outro lado, ao passo que a narrativa muda de registro e de estilo, também a viagem de Riverão pelo sertão muda de forma e rumo a todo o momento, tendo como resultado uma "travessia alucinatória":

[...] riverão, provável corruptela de ribeirão, é uma palavra-valise que, contendo river (rio) e verão (estação do ano e futuro do verbo ver), sintetiza o espaço e o tempo em movimento. Esse riverão exige uma travessia alucinatória porque, por sua vez, é um eixo mágico que atravessa os territórios do real, do imaginado e do vivido. [...] (FONSECA, 2012, p. 238 - grifo nosso).

Esse delírio, esse desatino, designado de "lisérgico" por Jair da Fonseca, posto que se assemelhe ao efeito de drogas que evocam realidades não presentes, remete ainda aos estados de alteração da consciência (provocados por drogas ou não) de um sujeito ou de um texto em transe. $O$ transe foi um dos procedimentos adotados pelo cineasta baiano, segundo esclarece em seus manifestos sobre a estética, por tratar-se de uma alternativa ao racionalismo e à subjugação colonial e de um dos vestígios do surrealismo nos trópicos. Em "Eztetyka do sonho", conferência apresentada na Universidade de Columbia, Nova Iorque, em 1971, Rocha argumenta que a revolução na América Latina deve partir de uma descontinuidade provocada pelo irracionalismo que advém das raízes ameríndias e africanas do continente, as únicas capazes de recusar o colonialismo: "Os Deuses Afro-índios negarão a mística colonizadora do catolicismo, que é feitiçaria da repressão e da redenção moral dos ricos" (ROCHA, 2004, p. 251).

A pobreza, para ele, também é produtora de polaridades, na medida em que transforma o homem em um "animal de duas cabeças", uma fatalista e submissa (dotado da "moral escrava", segundo afirmaria Nietzsche em Genealogia da moral, 1998) e a outra mística; esse sujeito estaria movido, portanto, por duas forças que se encontram eternamente em conflito, uma ativa e uma passiva. A revolução, assim, seria impulsionada pelo misticismo, "única linguagem que transcende ao esquema racional de opressão" (ROCHA, 2004, p. 251) e só pode ser mágica e imprevista, incompreensível pela razão dominadora. Nada muito distante, portanto, dos grupos de cangaceiros e das massas de seringueiros que se rebelam na "Áfrykzyameryka" diante da opressão e do abuso de Karter 
Bracker no texto Riverão Sussuarana, que não fortuitamente evocará heróis místicos como Antônio Conselheiro.

Roger Caillois, um dos fundadores do Colégio de Sociologia em 1937 com Georges Bataille e Michel Leiris, propôs uma sociologia dos jogos que discutia o simulacro (a mimicry ou a mímica) como uma de suas categorias, de forma semelhante à tragédia para Nietzsche, cujo ator assumia um estado onírico e extático, envolvendo-se tanto no arrebatamento dionisíaco como no efeito apolínio do sonho (NIETZSCHE, 2007). A mimicry, segundo Caillois, supõe que os participantes na atividade lúdica aceitem a entrada de si mesmos em jogo, "inlusio", e que o jogador "creia ou faça com que os demais creiam que é distinto de si próprio" (CAILLOIS, 1986, p. 52). Contrariamente ao mimetismo dos insetos, cuja "máscara" faz parte do corpo, a mimicry no homem consiste "em representar [jouer] uma personagem" (CAILLOIS, 1986, p. 53), assumindo uma função social diversa daquela que lhe cabia, libertando o indivíduo puramente ao instinto.

A mimicry, assim como a ilinix ou vertigem - a qual reúne os jogos não dotados de regras claras e que buscam destruir, momentaneamente, a estabilidade da percepção - são categorias culturalmente relacionadas às "sociedades de confusão", de acordo com Caillois, as ameríndias, as africanas e oceânicas, as quais se contrapõem às "sociedades da contabilidade" ou do progresso, aquelas que se organizam em instituições e perpetuam o controle dos aparelhos de Estado. Contudo, se a simulação dos jogos é fictícia, a possessão, como resultado do transe, nem sempre é simulada, ela se dá como se algo acontecesse no sujeito sem a sua participação, como no êxtase xamânico, provocado pelo canto e pela agitação convulsiva. Quando a representação dos animais sagrados combina-se à vertigem provocada pela dança e pela embriaguez, o sujeito mascarado e em transe identifica-se com a face da divindade que imita e deixa de discernir a própria individualidade.

Haveria, ainda, no cinema e no livro de 1978, o que poderíamos designar como o trânsito egocêntrico do "Glauber personagem". O cineasta invade o set de filmagem, deixando que a sua voz seja ouvida e o corpo do diretor em ação seja visto nas cenas, como se estivesse possuído pela "personagem-diretor" em filmes como A idade da terra (1980) (SOARES, 2005, p. 152-153). Como consequência do transe glauberiano, a figura do cineasta encontra-se incessantemente com a do herói e com a de outros duplos, as máscaras trágicas escolhidas por ele.

Desse modo, em uma carta escrita para Cacá Diegues quando se encontra exilado em Paris em 1972, Rocha se compadece do próprio sofrimento, pois havia recentemente perdido os rolos de Câncer (filmado naquele ano), confiscados pela alfândega francesa. Sem dinheiro, contava com o faturamento do filme para se manter e, diante do fato de que talvez fosse impossível lançá-lo e do seu isolamento, se compara a um pária social e a um mártir ao mesmo tempo: "[...] a solidão é terrível e sinto todas as feridas do país estourando no meu corpo e alma, e parece até o prenúncio da morte. [...] Parece até que roubei o fogo; virei Prometeu" (ROCHA, 1997, p. 447 - grifo nosso).

Como vemos, o titã é uma das personagens trágicas "incorporadas" pelo cineasta, a 
qual irá se delinear na prosa da mesma década como uma face entre as outras possíveis. Isso porque a narrativa está constantemente marcada pela metamorfose do eu em outro, segundo nota Jair Tadeu da Fonseca, "[...] como se o narrador, em sua performance verbal, fosse um diretor de cena, que representa o papel da personagem a ser desempenhado pelo outro, revezando-se com este" (FONSECA, 2012, p. 241). Isso se dá, inclusive, pela via da linguagem, que, como vimos, provoca aglutinações entre dois termos e sujeitos, por meio da justaposição de palavras ou da ausência de vírgulas, e também pela constante troca das vozes narrativas, que se alternam imponderavelmente da primeira para a terceira pessoa: "aquilo me persegue desde rapaz, mesmo antes do dia que fez seu primeiro serviço"; "Anjo se levantei, abriu a tampa azulada do vidro-cristal" (ROCHA, 2012, p. 27 - grifos nossos).

Em Riverão Sussuarana, o titã da tragédia de Ésquilo compõe os XII fragmentos de "PHROMETEU" (ROCHA, 2012, p. 194-198), uma das poucas seções ou passagens do texto que estão intituladas (as demais são os contos que intercalam a narrativa, dois deles atribuídos à irmã de Glauber), em geral mescladas ao desenvolvimento do enredo. Os textos estão escritos quase totalmente em letras maiúsculas e dispostos em colunas, recordando, assim, uma afinidade entre a estética escritural de Glauber Rocha e a poesia concreta. Os segmentos, todos enumerados, funcionam ao modo dos aforismos nietzschianos, que perfazem a sua potência em "lampejos de significados", e não procuram constituir qualquer sistema ou tratado filosófico, mas incluir a dubiedade no seio do conhecimento: "- A Filosofia não é Ciência porque seu Fundamento é a Dúvida - a Filosofia é conhecer sem Compromissos com o Conhecido" (ROCHA, 2012, p. 196).

Os trechos acerca do titã situam-se ao final da narrativa principal, em que a personagem Karter Bracker, o empresário estrangeiro explorador das minas de urânio, interfere na epopeia de Linda, Guimarães Rosa, Anjo Mauro e Riverão Sussuarana pelo sertão nordestino. O empresário procura descobrir o "Geo Fogo", referindo-se a uma noção positivista do desenvolvimento, que o impele ao progresso a todo custo, mesmo a despeito da violência (Karter defende o armamento brasileiro com a bomba atômica durante a guerra). Desse modo, simboliza o progresso histórico, a expansão do país ao interior com a construção de Brasília e a irrupção de conflitos como a revolução de 1930:

\author{
[...] cOMO Se PROMETEU FOSSE O FOGO NUCLEAR, \\ O NASCIMENTO DOS DEUSES \\ O NASCIMENTO DA CONSCIÊNCIA \\ O NASCIMENTO DA CIVILIZAÇÃO (ROCHA, 2012, p. 195).
}

Ademais, "PHROMETEU" sucede o trecho autobiográfico sobre Anecy Rocha, irmã de Glauber morta em um acidente em 1977, reportando-nos a uma ferida que assume ares ficcionais. Desse modo, não é fortuito que alguns dos segmentos forneçam uma reflexão sobre a morte, seja pela via da psicanálise ao evocar a dualidade freudiana entre Eros (o desejo) e Thanatos (a morte), seja pelo viés místico e poético. Assim, o autor insere os mortos em uma cosmologia, ao afirmar que cada um deles é uma estrela e se reintegra à 
máquina cósmica, e busca concebê-los, ainda, segundo a lei de transformação da matéria, ao equipará-los aos adubos e alicerces que se rematerializam em outros corpos.

Das remissões à tradição literária e cultural lusa, Rocha, que já havia evocado o sebastianismo messiânico, transcreve em caixa alta - como um indício de que, mais do que uma mera citação, trata-se de uma apropriação recriadora do texto - uma estrofe do soneto "Alma minha gentil que te partiste" de Camões. Assim, o luto pelo "espelho fêmea" do narrador, "Necy", mais adiante no texto, estimulará a transmutação dele em outro(a) ("Eras tão viva que continuas no meu corpo... Como se tivesse comido tu'alma minha Necy / Euyazado em Te...", p. 205). Por sua vez, o próprio titã Prometeu se apresenta como uma imagem andrógina, como se ele - criado pelos homens, detentor da cultura - se aproximasse de Pandora - invenção divina para punir os homens pelo advento do roubo do fogo na versão de Hesíodo, ou o narrador Glauber assumisse a sua face feminina: "o HOMULHER descobriu o fogo" (ROCHA, 2012, p. 195).

A oscilação entre os sexos é outra forma de introduzir o signo da diferença, procedimento adotado pela linguagem glauberiana, permeada pela resistência de uma letra, de um gesto: a letra " $Y$ ", também o cromossomo do gênero feminino, traveste essa linguagem neutra, exagerando na aparência daquilo que supostamente ela reproduz. Além disso, a consoante do alfabeto anglo-saxão, presente em Necy / Anecy, em termos como "eztetyka", "myzerya", "Áfrykzyameryka", entre tantos outros, se liga ao sistema latino formando palavras em português (os neologismos) que soam com familiaridade, mas se parecem com uma terceira língua que não conhecemos. Desse modo, África e América continentes subjugados que adotam o misticismo como forma de revolução - de acordo com Glauber Rocha em "Eztetyka do sonho", mimetizam a língua falada pelo colonizador e camuflam o seu discurso armando a tocaia contra o "Ocupante", antes que esse perceba estar face-a-face com o inimigo.

Com a releitura das tragédias de Ésquilo e de Hesíodo, Glauber Rocha reitera o efeito alucinatório da narrativa de Riverão Sussuarana e perfaz uma interpretação não-cronológica da gênese, ao valer-se no livro de um proto-gênero ou anti-gênero textual - a tragédia em meio aos outros textos. Ao situar-se próximo da ferida que "arrebentou a estrutura de 'Riverão Sussuarana'” (ROCHA, 2012, p. 177), "PHROMETEU” revela que a história pode ser constantemente deslocada a ressignificada por meio da estória, como afirma Guimarães Rosa-personagem no início do texto. Isso se dá quando a narrativa se encontra no intervalo entre a história e a imaginação, como a mitologia prometeica. Logo, no efeito de transe está implicada uma concepção diversa daquela do tempo da História (linear e cronológica), posto que esse se propague por começos incessantes, irrupções, por um vazio que não tem passado, como o sertão, porque é o choque e a fresta que existem entre o antes e o depois. O tempo é, assim, uma aproximação entre camadas de épocas diversas que transformam a história em duração e todas as etapas em atuais, de modo que coexistem e convivem Grécia Antiga (Prometeu) e religiões africanas (Xangô e Tupã), deuses luminosos da América Latina e da Europa: 
Todas as épocas são contemporâneas

Idade Média boliviana

Grecyazteca (ROCHA, 2012, p. 232).

O Prometeu pirofórico é condenado à tortura pelos próprios homens que não compreendem a potência do fogo revolucionário: "Não troco meu sofrimento pela vossa falsa liberdade nas trevas iluminadas pelas ilusões. Eu conheci o fogo e mesmo dele exilado sou a memória do seu fulgor..." (ROCHA, 2012, p. 195). Contudo, o detentor das luzes não é meramente uma alegoria do progresso, mas também um eco do culto solar que se manifesta na antiguidade por meio da figura de Apolo (a divindade da criação plástica, da beleza e da aparência tranquilas, portadora de um "olho solar", segundo Nietzsche, 2007).

Se o tempo de Prometeu é o do retorno, pois o seu fígado é devorado durante o dia e regenera-se a cada amanhã, o sol também poderá reportar-se, para o Georges Bataille de 0 ânus solar, a uma repetição periódica, a dos seus movimentos em torno de um centro móvel e a de seus encontros com a face escura planetária. O sol, noturno e erótico para o intelectual francês, contraria a destruição da guerra: "À fecundidade celeste opõem-se os desastres que são imagem do amor terrestre sem condição, ereção simpática sem saída nem regra, escândalo e terror" (BATAILLE, 1985, s. p.). Parte de uma série de outros princípios geradores, que também bailam circularmente, o sol em Glauber Rocha é uma das imagens do sertão escaldante, desdobrado em uma paisagem de múltiplos centros na narrativa, destituindo-nos da possibilidade de pensarmos em um sistema, pois o deserto sertanejo é como uma clareira que ultrapassa os limites da nação, indo do Grande Sertão Veredas à tragédia antiga.

Poderíamos aproximar, em Riverão Sussuarana, a versão do Prometeu solar a uma infinidade de outros mártires e messias, como Antonio Conselheiro, que se interpõem entre a organização da comunidade e o sistema. No entanto, apesar da presença de Conselheiro, o efeito do romance é o da desmistificação seja da linguagem, seja do nome próprio - uma vez que a assinatura não é senão uma máscara escritural que reformula os nomes próprios de Guimarães Rosa (Major e Mestre Rosa, Embaixador Romancista, Jango Rosa) e de Glauber Rocha (Glaubiru, Grober, Glaudi, seu Roxo), até que, por fim, o escritor mineiro e o cineasta mesclem-se na personagem Guimarães Rocha: um homem qualquer, uma bipolaridade formada pelo soberano e pelo homo sacer.

Prometeu, por outro lado, assume a forma do absoluto - daquilo que esconde algo em que poderia se tornar, uma categoria da representação livre de qualquer transcendentalidade (EINSTEIN, 2004). O autor esvazia, por conseguinte, as funções predominantes nas aparições desse mito, de modo que já não se refira a ao ato da criação divina, nem inaugure a civilização entre os homens, mas aponte para o "nada" característico do começo não progressivo:

\section{I} $[\ldots]$

Mais importante do que esses dois atos é o DURANTE que preenche 


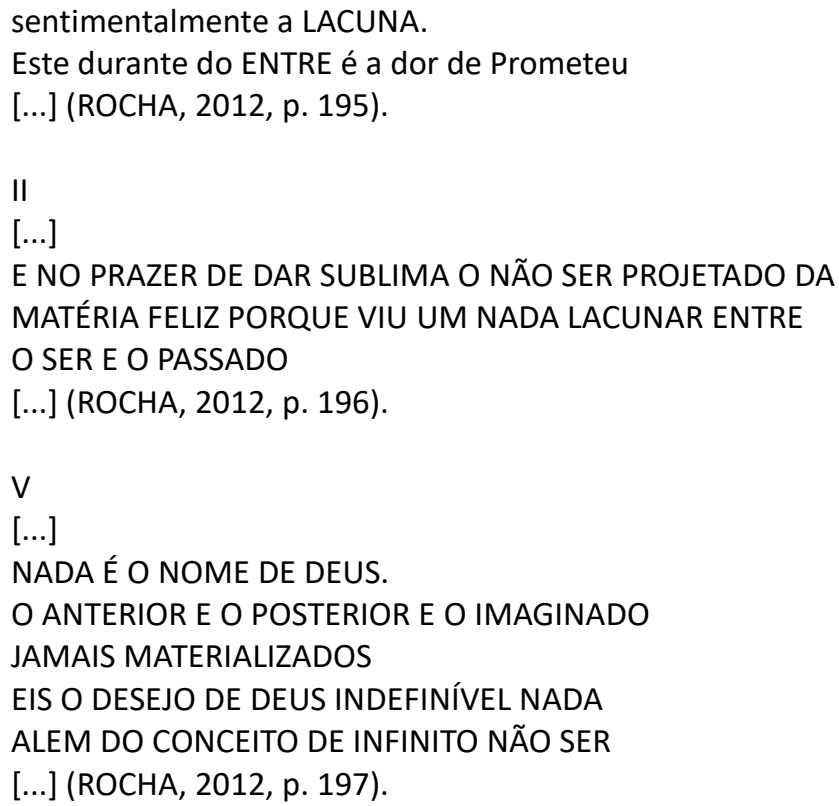

Herkunft e Erbschaft, empregados por Nietzsche para designar a origem, atuam como um sintoma ou um pathos, a presença de uma incompletude inevitável, ou seja, "um conjunto de falhas, de fissuras, de camadas heterogêneas que a tornam instável, e, do interior ou de baixo, ameaçam o frágil herdeiro" (FOUCAULT, 2007, p. 21). Como o filósofo italiano Roberto Esposito irá recordar contemporaneamente, o início nietzschiano não é exatamente uma questão temporal, mas de relação, na medida em que a divindade somente pode ser concebida na sua própria dissolução como Ser para dar origem ao homem, tornando-se, assim, "não-Ser". Portanto, no modelo bipolar de Glauber Rocha, o começo está tomado pela diferença e prescinde de toda a pretensão de unidade e de presença, pois carrega em si o traço de seu nascimento e o gérmen da criação, do vir a existir e do tornar-se outro, mesmo que momentaneamente.

\section{Deus no mundo}

Eu quis acender o espírito da vida

Quis refundir o meu próprio molde,

Quis reconhecer a verdade dos seres, dos elementos;

Me rebelei contra Deus,

Contra o papa, os banqueiros, a escola antiga,

Contra minha família, contra meu amor,

Depois contra o trabalho,

Depois contra a preguiça,

Depois contra mim mesmo,

Contra minhas três dimensões:

Então o ditador do mundo

Mandou me prender no Pão de Açúcar:

Vêm esquadrilhas de aviões

Bicar o meu pobre fígado.

Vomito bílis em quantidade, 
Contemplo lá embaixo as filhas do mar

Vestidas de maiô, cantando sambas,

Vejo madrugadas e tardes nascerem

- Pureza e simplicidade da vida! -

Mas não posso pedir perdão.

(Murilo Mendes, "Novíssimo Prometeu")

Embora possamos reconhecer correlações entre o cineasta do Cinema Novo e o autor de "Novíssimo Prometeu", segundo Luciana Stegagno Picchio (2012), o último se distingue do afã tropicalista do diretor de Terra em transe, residente na Europa no mesmo período que Murilo. Podemos destacar, ainda, como dissonância entre ambos a mesma característica que o poeta afirmava diferenciá-lo de Guimarães Rosa, evocado abundantemente (como personagem) em Riverão Sussuarana. De acordo com o intelectual católico em Retratosrelâmpago, ao contrário de Rosa (e, por consequência, de Euclides da Cunha e de Glauber Rocha), ele não se embrenhara pelos sertões mineiros ou nordestinos, nem dialogara com os sertanejos, em vida ou em seus poemas - indivíduos "telúricos, divinos e demoníacos" (MENDES, 1994, 1286). Ademais, poeta "católico, surrealista, barroco, metafísico, visionário e insubmisso" (PICCHIO, 2012, s.p.), ao combinar o seu interesse pela religião aos movimentos de vanguarda do período, Murilo concatenou dois polos equidistantes, incluindo a dimensão do desejo no sagrado e refutando que a possibilidade de verdades definitivas (ANTELO, 2006). Nessas caraterísticas, encontramos tanto vestígios da proximidade entre ele e o surrealismo dissidente internacional e como da doutrina católica do amigo e artista Ismael Nery, conforme veremos na leitura do poema "Novíssimo Prometeu", em que o dionisíaco nietzschiano se combina ao mito grego.

Conforme vimos, o Prometeu acorrentado de Ésquilo, ao lado da figura eternamente errante de lo, nos faz compreender que a punição executada por Cronos (ou Zeus) pelo roubo do fogo revela um fato oculto da história: o de que a contingência e o movimento de lo rumo ao fim dos tempos serão interrompidos pelo retorno dos mártires e pela incessante renovação do sofrimento. Essa qualidade do mito prometeico foi enfatizada na retomada nietzschiana da tragédia grega, que recupera a condição impura desse relato. Apresentando ainda uma afinidade com a vertente romântica do mito, a do poema de Goethe, o filósofo alemão afirma que a ânsia esquiliana de conferir ao titã o dilaceramento do seu corpo devolve a esse mito outra máscara possível, além da de seu irmão Atlas: a de Dioniso:

Esse afã titânico de ser como que o Atlas de todos os indivíduos, e carregá-los com a larga espádua cada vez mais alto e cada vez mais longo, é o que há de comum entre o prometeico e o dionisíaco. O Prometeu esquiliano é, nessa consideração, uma máscara dionisíaca, ao passo que, no profundo pendor para a justiça antes mencionado, Ésquilo trai, ao olho penetrante, a sua descendência paterna de Apolo, o deus da individuação e dos limites da justiça (NIETZSCHE, 2007, p. 66 - grifo nosso).

De acordo com o filósofo alemão, na tragédia de Ésquilo, Prometeu é um nome dado ao 
artista titânico que expia pelo sofrimento ao se propor a produzir seres humanos e aniquilar os deuses olímpicos, mas que também se sente estupefato diante do "vir-a-ser do artista, a alegria da criação artística a desafiar todo e qualquer infortúnio" (NIETZSCHE, 2007, p. 64), como a sua vertente plasticator. Prometeu também seria (além de Édipo e de outros heróis) a forma aparente da face de Dioniso, o proto-herói e primeiro ator, que fora despedaçado pelos titãs e depois idolatrado como Zagreus, de modo a abrigar em si a dupla essência de "um cruel demônio embrutecido" e de um "brando e meigo soberano".

A revista parisiense Acéphale, cujos cinco números foram publicados entre 1936 e 1938, dedicara-se especialmente a refutar o uso nietzschiano pelo nazismo e a enfatizar o aspecto dionisíaco do pensamento. Nesse sentido, não é de se estranhar que os números 3 e 4 evoquem a filosofia de Dioniso, deus que era filho de Zeus e de uma mortal, Sêmele, nascido do corpo aniquilado de sua mãe, e tantas vezes despedaçado e retornado da destruição. A divindade, que, para Nietzsche, teria instilado a insurgência ativa de Prometeu, é lida por Jules Monnerot (2014), martinicano e também um dos fundadores do Colégio de Sociologia, como o intercessor entre o poder e a ordem e responsável pela denúncia da arbitrariedade do primeiro (MONNEROT, 2014). O filósofo dionisíaco, para ele, resgata um sentido esquecido da palavra "ressentimento", o qual expressaria a indignação colérica. Por sua vez, para Georges Bataille (em "Crônica nietzschiana"), o pensador alemão demandaria, por meio da tragédia, a vontade de potência do indivíduo, de combater o "céu carregado da necessidade de punir" (BATAILLE, 2014, p. 20). Por fim, essa arte simbolizaria, aos idealizadores do Colégio de Sociologia, uma forma de comunidade anárquica, reunida tanto pela ausência de um chefe, como pela embriaguez e pelo êxtase coletivos. Embora o poeta mineiro refute o anticristianismo nietzschiano (valor enfatizado por Bataille, por exemplo), mostrou-se apto a recuperar uma dimensão impura do sagrado debatida por intelectuais como Roger Caillois, ao incorporar o êxtase dionisíaco no seu próprio comentário sobre a religião.

"Novíssimo Prometeu" pertence ao livro O visionário, escrito entre 1930 e 1933 e publicado somente em 1941 que, como A poesia em pânico (1937), é reconhecido como um dos mais surrealistas de Murilo. Nos versos desse autor, prefigura-se uma religiosidade quase mundana, expondo a laceração da carne e a violência dos regimes ditatoriais do período como aquela presente na imagem dionisíaca -, que se apropriam dos corpos, dos gestos e fazem novo uso da vida mesma, reduzida a uma condição inumana e a um mecanismo de controle. Mendes aproxima a divindade do labor do poeta, quem funde e refunde o molde da linguagem em sua tarefa e se manifesta politicamente contra o fascismo, como faria ao longo de sua trajetória escritural. O resultado da síntese entre a acefalia e a religião seria o que Mário de Andrade denominou, em "A poesia em pânico" (1946), de uma religião desprovida de universalismo e ou de verdades incontestáveis, em consonância com Raúl Antelo: 
religião, além de um não raro mau gosto, desmoraliza as imagens permanentes, veste de modas temporárias as verdades que se querem eternas, fixa anacronicamente numa região do tempo e do espaço o Catolicismo, que se quer universal por definição (ANDRADE, 1972, p. 46-47).

De fato, a observação de Andrade é pertinente: o que lemos na poesia de Murilo é uma concepção anacrônica da eternidade, nem sempre pautada na possibilidade da redenção por meio do encontro com o divino, pois se insurge contra os próprios dogmas em que se baseia, travestindo a igreja com corpos femininos e somando o amor pela virgem ao amor pela mulher mundana, como vemos nos seguintes versos de "A destruição", de A poesia em pânico: "Ó Madalena, tu que dominaste a força da carne / Está mais perto de nós do que a Virgem Maria, / Isenta, desde a eternidade, da culpa original" (MENDES, 1994, p. 287). No poema prometeico, contudo, em que qualquer vestígio da divindade se reduz a Zeus como algoz ou como grande ditador, os corpos femininos seminus - das mulheres no mar, de maiô, sereias ou nereidas - coexistem com o sofrimento do herói, reconstituindo o laço dionisíaco entre a dor e o gozo en retard.

O espírito e a essência se transformam nas pedras que rolam pelos poemas de 0 visionário, o horror da guerra se espelha na carne e modifica os homens comuns e os santos em rocha. Em poemas como "O doente do século", "A cadeira elétrica" e "Mas" não existe uma separação entre a geografia do Cáucaso e o fígado de Prometeu, dado que o organismo resuma-se a estilhaços solidificados e as pedras pesem sobre um corpo decapitado:

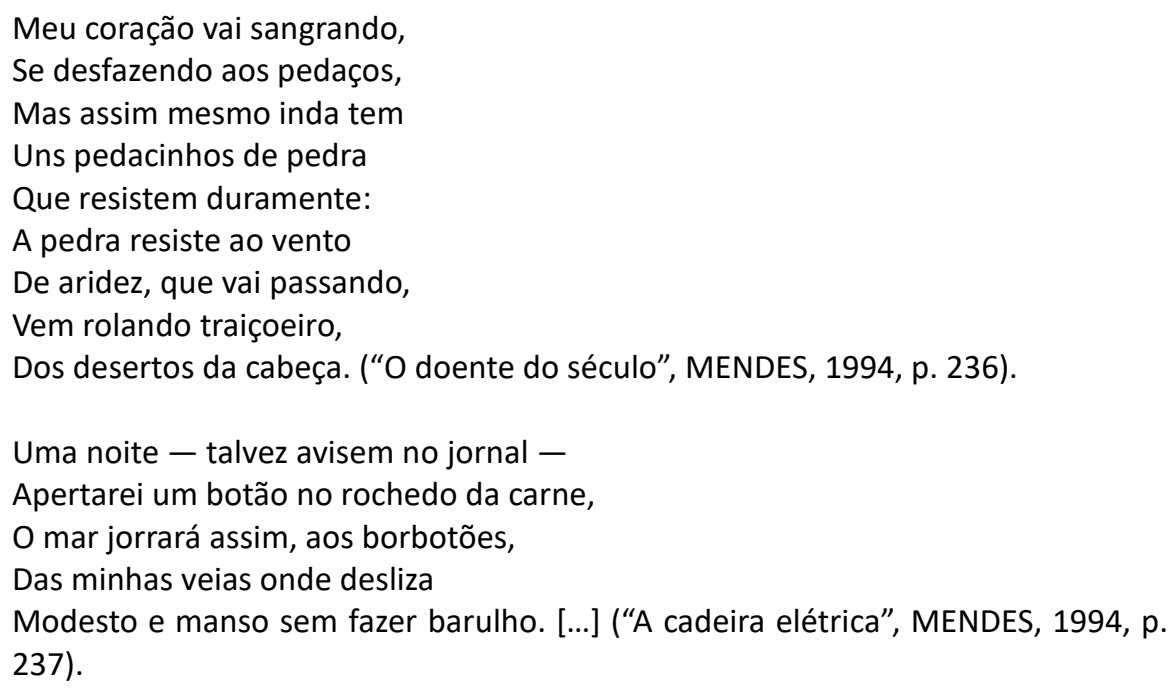

Com o seu título, "novíssimo", e as remissões sutis à guerra e às suas tecnologias - 
com os termos "ditador do mundo" e as "esquadrilhas de aviões", que devoram o corpo ao invés de bombardeá-lo, o poema de Murilo Mendes atualiza o mito grego permitindo a convivência entre a Antiguidade e o presente. O reconhecimento da fusão entre criador e criatura, em "Novíssimo Prometeu", permite ao sujeito-lírico recusar-se a submeter-se a uma hierarquia superior, confessando os supostos lapsos e apropriando-se da culpa (verso 20). Se há alguma comunhão possível nesse poema, essa se dá entre os homens e uma divindade que somente pode estar presente como retirada, pois "NADA É O NOME DE DEUS", como escreveria Glauber Rocha. Segundo Martin Heidegger constatara acerca da poesia de Hölderlin, quando se pergunta se seria possível a poesia em tempos de penúria como a guerra, o esplendor divino teria se perdido com o sacrifício do Cristo, inaugurando uma era sem Deus e sem os heróis. Contudo, esse hiato deixado pelo seu afastamento, situado na fenda entre céu e terra, é o lugar e o momento em que o ser se cria com o apagamento de sua autoridade, quando e onde o seu pensamento se transmuta em poesia, reafirmando a existência dessa arte mesmo por entre os escombros (HEIDEGGER, 1998).

Vale recordar que a noção de tempo implicada em Murilo deve-se em grande parte ao essencialismo de Ismael Nery, quem conhecera em 1922. Como sabemos, o autor de Bumba-meu-poeta (1930-1931) reuniu os escritos de Nery sobre essa doutrina na revista A Ordem, fundada por Jackson Figueiredo em 1921. O essencialismo procurava garantir a "superação" do homem por meio da abstração do tempo e do espaço, a que o ser humano deveria sujeitar-se. Além disso, o homem deveria submeter todas as suas ações e envolverse apenas com os fatos essenciais ao seu "Bem" (ou "tudo o que nos conduz à morte naturalmente sem atacar a nossa dose de instinto de conservação"). Visto que, para o essencialismo, a vida seria um processo de construção do conhecimento, um

[...] não desviar-se de um destino inevitável e preservar-se no percurso até um futuro previsto, uma reconstrução que se inicia com o nascimento e finda com a morte. Todo o homem possui um coeficiente de energia e de tempo determinado que não poderá ser desperdiçado sem prejuízo final (MENDES, 1935, p. 315-316 grifo do autor).

Em "Novíssimo Prometeu", a abstração do tempo e do espaço se dá com a perda das margens corpóreas, como se Prometeu se tornasse quase plano e se confundisse mimeticamente com o Pão de Açúcar (o qual substitui o Cáucaso da tragédia esquiliana), pois o poeta rebela-se contra a divindade e contra as "três dimensões" do seu corpo. O sujeitolírico não cessa, igualmente, de demonstrar a aspiração de tornar-se o próprio regente de seus domínios e deixar de servir como a peça submissa de uma engrenagem. Nesses termos, o poeta reforça uma posição quase terrena da espiritualidade e a sua vizinhança com um Deus que combina a luz ("Eu quis acender o espírito da vida") ao sofrimento no mundo. Nas "Proposições sobre o fascismo" publicadas por Georges Bataille no segundo número da revista Acéphale (1937), o intelectual francês compreende o conceito de liberdade em Nietzsche à semelhança da aspiração prometeica, pois, para o filósofo, ser livre significaria 
não submeter a vida a uma função, nem reconhecer a autoridade consciente ou Deus (o Zeus da mitologia prometeica), simbolizada pela cabeça e pela unidade entre as funções servis do corpo.

No entanto, quando o herói se confunde com a divindade cristã faz eco àquele que estimula o sofrimento e a dor daqueles que contemplam a sua expiação. O herói como mártir também foi discutido pelo artista brasileiro Flávio de Carvalho, amigo do escritor mineiro e autor do Retrato de Murilo Mendes (1951) e do grafite Cabeça do poeta Murilo Mendes, do mesmo ano, que também esboçou uma relação intensa com a cultura italiana. Murilo, além de ter vivido em Roma por dezoito anos, compusera o livro Ipotesi em italiano, publicado postumamente em 1977; Carvalho redigira uma série de 65 textos cuja primeira parte se intitulara, justamente, Os gatos de Roma, publicada no Diário de S. Paulo a partir de 1957, cuja primeira parte se remete à estada do autor na capital italiana no ano anterior para desfilar o seu traje de verão masculino e expor na Galeria L’Obelisco.

Segundo nos esclarece Flávio de Carvalho em "As feridas abertas da arqueologia. O europeu quer a guerra", da coletânea de textos mencionada, existe uma diferença entre a ética sul-americana e a europeia, dado que o primeiro desses povos se valeria de uma atitude pacífica diante das feridas abertas, sendo, ainda, incapaz de reconhecer atrás de si a tradição e estaria tomado por um erotismo pueril. Por sua vez, o autor constata uma necessidade europeia de manter as feridas abertas de sua arqueologia e de sua História, um desejo de "perpetuar o sofrimento e a dor" contemplando a imagem do Cristo em feridas. Essa "conduta beática" diante de passado, associada ao constante desejo do velho continente de instigar os conflitos bélicos, encontraria correlato na tragédia antiga, a qual representava o padecimento do herói por suas faltas, substituído pelo primeiro ator (um único ator, o bailarino solitário), o deus Dioniso, que padecia em decorrência da sua insurgência contra a divindade suprema e das faltas cometias pelo coro (FREUD, 1996):

\footnotetext{
A beatitude arqueológica, que visa conservar as feridas abertas, torna-se uma manifestação do masoquismo e narcisismo, onde o contemplador se admira a si mesmo como herói, sendo a sua pessoa transformada para esse fim em ruína arqueológica. O beato-contemplador é sempre consequência do escrúpulo moral. Há um destino da ferida na arqueologia europeia; ela deve ser mantida aberta para conservar sempre vivo o espetáculo voluptuoso da dor, sustentando dessa maneira a ética proveniente dos escrúpulos morais gerados na tradição. (CARVALHO, 2019, p. 73).
}

O poema de Murilo Mendes, entretanto, combina atitudes ambivalentes diante do martírio, o lado passivo - o da soberania régia e divina - e o lado ativo, o da ética individual diante das convenções. A ação e a passividade dividem os dois conjuntos de dez versos do poema. Em sua primeira parte, por meio dos verbos em primeira pessoa ("quis" e "rebelei"), o texto faz jus à versão esquiliana - na qual Prometeu afirma que quis cometer o seu crime para libertar os mortais - e o poeta prometeico esboça a sua potência de recriar a realidade existente e de refundar a tradição, a sua recusa às instituições e à opressão que elas 
representam ("Deus", "papa", "banqueiros", "família"), bem como a própria consequência dos seus atos. Assim, o titã se insubordina tanto contra o trabalho (um dos males libertados pela caixa de Pandora), como contra o ócio e a preguiça. Não obstante, nos dez últimos versos do poema, advém a punição divina e os verbos em terceira pessoa se remetem ao suplício do titã ("mandou", "vêm") e à sua recepção inerte do castigo ("vomito", "contemplo") (ALVES; CODINHOTO, 2010). Por fim, atividade e inatividade se reúnem pela justaposição de uma partícula negativa que, combinada ao verbo "poder" ("Mas não posso pedir perdão"), sugere uma decisão ética por excelência, a de recusar a norma e a sujeição aos desígnios alheios. A negação transmuta um suposto "não poder" (passivo), significando não ter habilidade ou permissão para, em um "preferir não" ou um "não querer" (ativo), que reinsere o sujeito no mundo pela via da linguagem e da "vontade de potência". Criam-se, destarte, uma região limiar e a simultaneidade entre os atos de dizer ("pedir perdão") e o silêncio, bem como a circularidade de "Novíssimo Prometeu", o qual se inicia e termina com duas formas diversas de resistência do titã.

Bem sabemos que os movimentos de vanguarda como o surrealismo e o dadaísmo reconhecem a debilidade do esforço de repor a totalidade corpórea. Por essa razão, esboçam o retorno dessa percepção de maneiras diversas na arte, valendo-se das descobertas freudianas do inconsciente nos experimentos poéticos, tais como a escrita automática, procedimento muito empregado entre os surrealistas reunidos em torno de André Breton para criar um texto fragmentário como as bonecas desconexas de Hans Bellmer. Além disso, nos periódicos surrealistas do período, nas revistas Documents, Acéphale e Minotaure, nas quais figuram diversas ilustrações da autoria de André Masson, o corpo humano surrealista, rasgado, expõe a carne e as deformidades, reportando-nos a uma condição de animalidade que desmorona com o racionalismo e com os anseios de completude. Recordemos, nesse sentido, do corpo do sujeito-lírico do poema "O doente do século", petrificado e fragmentado, com o coração em estilhaços e a cabeça substituída pela aridez do deserto.

Como vimos, Murilo Mendes, se aproximou do movimento surrealista especialmente por meio do seu contato com artistas como o pintor e escritor Ismael Nery; a partir de 1957, já em Roma, participa do círculo intelectual de Alberto Magnelli (1881-1971), René Magritte (1898-1967), Jean Arp (1886-1996) e Max Ernst (1891-1976). Escrito nessa época, o livro Retratos-relâmpago (1973), parte da obra madura de Murilo Mendes, se apresenta como um campo de forças no qual se encontram em confronto imagens relampejantes em que o arcaico e o moderno, a consciência e a inconsciência são vistos como contemporâneos (HONESCO, 2012), procedimento similar ao dos aforismos prometeicos de Glauber Rocha. Em um desses retratos ligeiros, relata o contato travado com André Breton em Paris entre 1951 e 1952 e a sua descoberta do surrealismo no Rio de Janeiro na década de 1920. Embora não tenha aderido ao movimento em conformidade absoluta, diz ter extraído dele uma "versão tropical": 
Abracei o surrealismo à moda brasileira, tomando dele o que mais me interessava: além de muitos capítulos da cartilha inconformista, a criação de uma atmosfera poética baseada na acoplagem de elementos díspares. Tratava-se de explorar o subconsciente; de inventar um outro frisson nouveau, extraído à modernidade; tudo deveria contribuir para uma visão fantástica do homem e seus possibilidades extremas (MENDES, 1994, 1238).

Esses elementos aparentemente dissonantes estão presentes em "Novíssimo Prometeu", no qual vemos a imagem de um novo homem que se ergue sobre os estilhaços da violência da guerra, talhado em pedra, vianda e sangue: um Prometeu compósito, um Prometeu-Dioniso, como aquele sugerido pelos colaboradores da revista Acéphale. Vale recordar que o mote para a revista Acéphale deriva da ilustração de André Masson de um corpo cujo sexo é substituído por um crânio descarnado e que apresenta uma tocha posicionada na mão esquerda (MARTínEZ, in: BATAILLE et al., 2010), uma chama prometeica. Para Bataille e Monnerot, o corpo decomposto de Dioniso remete-se ao globo em ebulição e ao homem do entre-guerras. Murilo Mendes reivindica esse mesmo aspecto telúrico e transmutador da obra de Friedrich Nietzsche no retrato-relâmpago sobre o filósofo alemão:

Sou grato a Nietzsche por certas palavras: "o espírito que dança"; "criação de novos valores"; "tudo o que não me faz morrer torna-me mais forte"; "o poder oculto da alma"; "no homem acham-se reunidos criatura e criador".

[...] Renovar sua didascália sobre o espírito grego como ponto de partida da cultura, e sobre o espírito israelita como organizador da ação. Desnazificar Nietzsche. Desprussianizá-lo.

Transcristão? Interpreta a disciplina do sofrimento. Cada cristão deveria explorar a parte de Dionísio que lhe toca (MENDES, 1994, p. 1210).

O titã do poema de Murilo não lamenta os sofrimentos de que padece, mas carrega a punição que lhe é destinada como o Atlas levaria o mundo sobre as costas, troçando das consequências para a humanidade, dado que se insurja até mesmo contra os valores que o seu ato supostamente tornaria possíveis, de modo que se aproxime do revolucionário anarquista. Por sua vez, o modelo bipolar de Glauber Rocha concebe a origem como um momento falido, que não cessa de se efetuar no presente, desestabilizando o tempo progressivo. Seja na variedade acefálica de Murilo Mendes ou na bipolar de Glauber Rocha, o mito de Prometeu nos reporta a um começo não unitário, suscitado pelo conflito entre forças de assenhoramento e de subjugação, que retorna em eventos diversos atualizando a História - dos fascismos e das ditaduras latino-americanas - por meio da Antiguidade, ao modo da genealogia nietzschiana.

\section{Referências}


ANDRADE, Mário. O empalhador de passarinho. 3. ed. São Paulo: Martins; Brasília: INL, 1972. ANTELO, Raúl. Murilo, o surrealismo e a religião. Boletim de Pesquisa NELIC, Florianópolis, v. 6, n. 8/9 - Poesia: passagens e impasses, p. 4-17, 2006.

ANTELO, Raúl. A era do abutre: modernismo e contra-modernismo. 2010. Inédito.

ALVES, Wanderlan da Silva; CODINHOTO, Diego de Jesus Rosa. O mito prometeico na trajetória poética de Murilo Mendes. Guavira Letras: o texto poético, comparativismo, fontes primárias e outras semioses, Três Lagoas-MS, n. 10, p. 72-87, ago.-dez. 2010.

BATAILLE, Georges. O ânus solar. Tradução de Aníbal Fernandes. Lisboa: Hiena, 1985.

BATAILLE, Georges. Proposições [sobre o fascismo e sobre a morte de Deus]. Tradução de Fernando Scheibe. Acéphale, n. 2 - Nietzsche e os fascistas: uma reparação. Florianópolis: Cultura e Barbárie, 2013.

BATAILLE, Georges. Crônica nietzschiana. Tradução de Fernando Scheibe. Acéphale, n. 3/4 Dionisos. Florianópolis: Cultura e Barbárie, 2014, p. 15-25.

BENTES, Ivana (Org.) Glauber Rocha - Cartas ao Mundo. São Paulo: Companhia das Letras, 1997.

CAILLOIS, Roger. Los juegos y los hombres. La máscara y el vértigo. Traducción de Jorge Ferreiro. México: Fondo de Cultura Económica, 1986.

CARVALHO, Flávio de. A moda e o novo homem. Rio de Janeiro: Azougue Editorial, 2010.

CARVALHO, Flávio de. As feridas abertas da arqueologia. O europeu quer a guerra. In: . Os gatos de Roma; Notas para a reconstrução de um mundo perdido. Organização, estabelecimento do texto, notas e pesquisa bibliográfica de Larissa Costa da Mata. Florianópolis: Universidade Federal de Santa Catarina, 2019, p. 72-74.

CÁMARA, Mario. Coisa gritante: o sertão de Glauber entre o corpo e a política. In: ROCHA, Glauber. Riverão Sussuarana. Florianópolis: Universidade Federal de Santa Catarina, 2012, p. 249-261.

EINSTEIN, Carl. Revolution Smashes Through History and Tradition. Translation Charles W. Haxthausen. October, n. 107, p. 139-145, Winter, 2004.

ESPOSITO, Roberto. El origen de la política. ¿Hannah Arendt o Simone Weil? Traducción de Rosa Rius Gatell. Barcelona, Buenos Aires: Paidós, 1999.

ÉSQUILO. Prometeo encadenado. In: GUAL, Carlos García. Prometeo: mito y literatura. Madrid: FCE, 2009, p. 49-82.

FONSECA, Jair Tadeu da. Glauber Rosa e Guimarães Rocha. In: ROCHA, Glauber. Riverão Sussuarana. Florianópolis: Universidade Federal de Santa Catarina, 2012, p. 237-247.

FREUD, Sigmund. Totem e tabu [1912-13]. In: . Obras Completas de Sigmund Freud.

Rio de Janeiro: Imago, 1996. v. XIII. 
FOUCAULT, Michel. Microfísica do poder. Organização de Roberto Machado. 23. ed. Rio de Janeiro: Graal, 2007.

GUAL, Carlos García. Prometeo: mito y literatura. Madrid: FCE, 2009.

HEIDEGGER, Martin. Para quê poetas? Tradução de Bernhardt Sylla e Vitor Moura. In: Caminhos de floresta. Lisboa: Fundação Calouste Gulbenkian, 1998, p. 309-367.

HESíODO. Teogonía (v. 507-616). Trabajos y días (v. 42-105). In: GUAL, Carlos García. Prometeo: mito y literatura. Madrid: FCE, 2009, p. 27-35.

HONESCO, Vinícius Nicastro. Murilo Mendes, Pier Paolo Pasolini e as religiões de seus tempos. 2012. 341 f. Tese (Doutorado em Literatura). Centro de Comunicação e Expressão; Programa de Pós-Graduação em Literatura, Universidade Federal de Santa Catarina, Florianópolis, 2012.

MARTínEZ, Margarita. Posfacio. In: BATAILLE, Georges [et al]. Acéphale. 3. ed. Traducción de Margarita Martínez. Buenos Aires: Caja Negra, 2010, p. 63-70.

MENDES, Murilo. Comentários aos poemas de Ismael Nery. A Ordem, Rio de Janeiro, p. 315317, abr. 1935.

MENDES, Murilo. Poesia completa e prosa. Organização, preparação do texto e notas: Luciana Stegagno Picchio. Rio de Janeiro: Nova Aguilar, 1994.

MONNEROT, Jules. Dionisos filósofo. Tradução de Fernando Scheibe. Acéphale, n. 3/4 Dionisos. Florianópolis: Cultura e Barbárie, 2014, p. 9-14.

NIETZSCHE, Friedrich. Genealogia da moral. Uma polêmica. Tradução de Paulo César de Souza. São Paulo: Companhia das Letras, 1998. Reimpressão.

NIETZSCHE, Friedrich. O nascimento da tragédia ou helenismo e pessimismo. Tradução de J. Guinzburg. São Paulo: Companhia das Letras, 2007.

PICCHIO, Luciana Stegagno. O retorno de Murilo Mendes. In: MENDES, Murilo. Murilo Mendes - Melhores poemas. Rio de Janeiro: Global Editora, 2012, s.p. [versão e-book].

ROCHA, Glauber. Eztetyka do sonho. In: Revolução do Cinema Novo. São Paulo: Cosac \& Naify, 2004, p. 248-251.

ROCHA, Glauber. Riverão Sussuarana. Florianópolis: Universidade Federal de Santa Catarina, 2012.

SOARES, Luis Felipe. Glauber Evangelista. Cinemais, Revista de Cinema e Outras Questões Audiovisuais. Rio de Janeiro: Aeroplano, 2005. 